\title{
The Development of Religious Personality Module Based on MRPI Model and AI-Ghazali Religious Personality Model
}

Noraini Ismail, Mardzelah Makhsin, Ummi Syarah Ismail, Syuhaida Idha Abd Rahim, Zainab Mohd Zain

To Link this Article: http://dx.doi.org/10.6007/IJARBSS/v11-i12/11818

DOI:10.6007/IJARBSS/v11-i12/11818

Received: 06 October 2021, Revised: 10 November 2021, Accepted: 24 November 2021

Published Online: 17 December 2021

In-Text Citation: (Ismail et al., 2021)

To Cite this Article: Ismail, N., Makhsin, M., Ismail, U. S., Rahim, S. I. A., \& Zain, Z. M. (2021). The Development of Religious Personality Module Based on MRPI Model and Al-Ghazali Religious Personality Model. International Journal of Academic Research in Business and Social Sciences, 11(12), 767-775.

Copyright: @ 2021 The Author(s)

Published by Human Resource Management Academic Research Society (www.hrmars.com) This article is published under the Creative Commons Attribution (CC BY 4.0) license. Anyone may reproduce, distribute, translate and create derivative works of this article (for both commercial and non0-commercial purposes), subject to full attribution to the original publication and authors. The full terms of this license may be seen at: http://creativecommons.org/licences/by/4.0/legalcode

Vol. 11, No. 12, 2021, Pg. 767 - 775

Full Terms \& Conditions of access and use can be found at http://hrmars.com/index.php/pages/detail/publication-ethics 


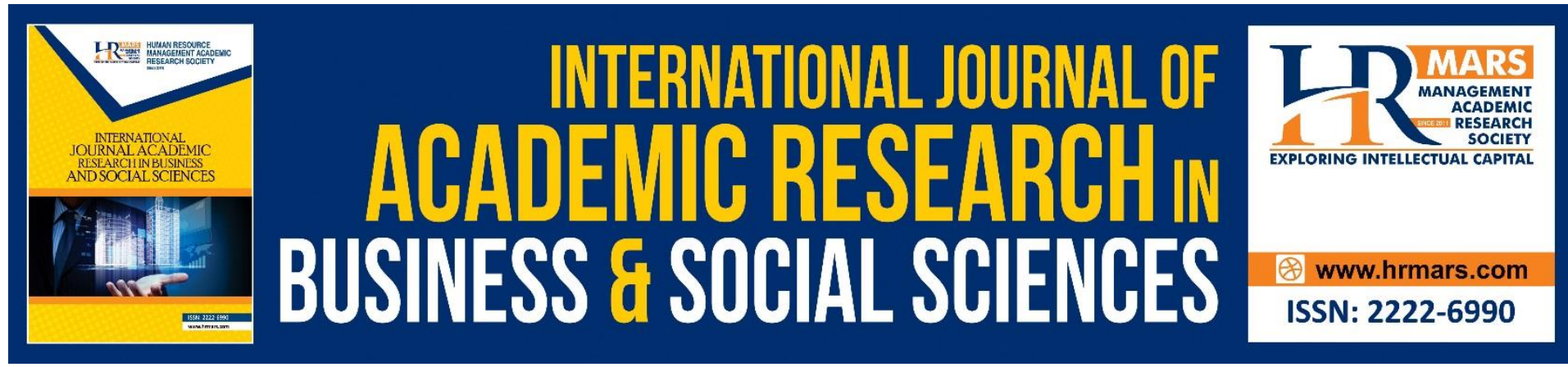

\title{
The Development of Religious Personality Module Based on MRPI Model and Al-Ghazali Religious Personality Model
}

\author{
Noraini Ismail ${ }^{1}$, Mardzelah Makhsin², Ummi Syarah Ismail ${ }^{3}$, \\ Syuhaida Idha Abd Rahim ${ }^{4}$, Zainab Mohd Zain ${ }^{5}$ \\ ${ }^{1}$ Universiti Teknologi MARA Cawangan Perlis, Kampus Arau, Malaysia, ${ }^{2}$ Northern University \\ of Malaysia, Malaysia, ${ }^{3}$ Universiti Teknologi MARA Cawangan Perlis, Kampus Arau, \\ Malaysia, ${ }^{4}$ Universiti Teknologi MARA Selangor, Malaysia, ${ }^{5}$ Universiti Teknologi MARA \\ Cawangan Melaka, Kampus Lendu, Malaysia
}

\begin{abstract}
Religious personality is closely related to the concept of religiosity where Muslim behavior is shaped by appreciation and practice in religion. An individual with a religious personality refers to an individual who has a personality or behavior that results from the great influence of aspects of religiosity on his life as a Muslim. This study aims to develop a Religious Personality Module based on al-Ghazali's Religious Personality Model and the MRPI (Muslim Religiosity-Personality Inventory) Model. Module construction is based on the Sidek Module Development Model. The process of identifying the content of the module is from a critical and extensive literature review. This study produced a draft module that has six constructs based on the dimensions of religious personality in MRPI Model, namely a relationship with Allah SWT, a relationship with human beings, a relationship with oneself and a relationship with nature. Each construct is divided into sub-constructs based on al-Ghazali's Religious Personality Model, namely mujahadah al-nafs and riyadhah al-nafs which are the basis for the construction of twelve activities in the module. Thus, further studies are recommended to explore the validity and reliability of the module draft before testing its effectiveness in enhancing the religious personality of Muslim.
\end{abstract}

Keywords: Module Development, Al-Ghazali Religious Personality, Riyadhah al-Nafs, Mujahadah al-Nafs, MRPI Model

\section{Introduction}

Religious personality refers to the personality and outlook on life of a person guided by the teachings of Islam. According to Krauss et al (2005), these religious personalities include behaviors, motivations, attitudes and emotions that describe obedience to Allah SWT and Rasulullah SAW. Individuals who have a good religious personality make religion a way of life and practice the teachings of religion comprehensively. Similarly, the aspect of mu'amalat is to maintain a relationship with Allah SWT, human relationships, relationships with oneself and also relationships with the environment (Krauss et al., 2005). Muslim individuals who 
have a good religious personality will produce a Muslim society with a high level of religious appreciation including aspects of faith, worship and morals (Ghani \& Mansor, 2006), while a low level of religious personality will drag Muslim individuals to the slander of the world and constructing negative behaviors (Ismail et.al., 2021; Ghani \& Musa, 2018). Therefore, the construction of religious personality should be given attention in the Islamic education system to ensure that religion is not only learned as a form of knowledge that is theoretical but practiced in all aspects of life of every Muslim.

In addition, the construction of a good religious personality among students can also help students in dealing with various issues and psychosocial problems and can also help produce students with a balanced personality and academics. The study of Hamjah, Rozali, Rasit \& Ismail (2012) has proven that there is a significant relationship between religious practices and students' academic achievement. Apart from that, the religious element is also a factor that can reduce various psychosocial problems that involve students nowadays (Ismail et.al, 2021). Studies conducted by Muhammad \& Omar (2017); Ali (2006); Bakar (2011) show that lack of appreciation of religion is among the factors that cause university students to be involved with various problems. Therefore, with the various initiatives taken to increase the appreciation and religious personality among students, it is hoped that it can overcome various problems that occur.

In the context of Malaysia, the government has taken various initiatives to increase the level of appreciation of religion and also religious personalities among the community, especially students. One of the methods used is through the Islamic spiritual mentoring system involving peers known as 'halaqah' or 'usrah'. Thus, this study aims to build a draft of religious personality module based on the MRPI Muslim Religiosity-Personality Inventory Model (Krauss et al., 2005) and also al-Ghazali Religious Personality Model (Sham et al., 2013) specifically for the use of peer Islamic spiritual mentoring programs at the school and university levels. The integration of al-Ghazali's Religious Personality Model and MRPI Model in the construction of this religious personality module is a new approach applied in the construction of an Islamic perspective module that is oriented towards peer guidance. The process of identifying module content is based on a critical and extensive literature review and by making the Sidek Module Development Model as the basis for module construction. This study produced a draft module with four constructs based on the MRPI religious personality dimension. Each construct is divided into sub-constructs based on al-Ghazali's Personality Construction Model, namely mujahadah al-nafs and riyadhah al-nafs which are the basis for the construction of twelve activities in the module.

\section{Methodology}

The collection of information is through literature review and library research which includes references from books, theses, journal articles, reports and related policies. This extensive and critical information search is done to determine the content of the module. Adequate information is important in making an accurate justification accordance with the scope of the study and the preparation of a draft for religious personality module.

\section{Result \& Discussion}

Module Development Model 
The Sidek Module Development Model (Sidek \& Jamaluddin, 2005) has been used as a basic guide in the construction procedure of the draft Religious Personality Module. This model includes two stages, namely the module draft preparation stage and the module testing and evaluation stage. There are nine steps in preparing a module draft starting with goal construction up to the consolidation of the module draft. This study did not go through the testing and evaluation stage of the module as it only focused on the construction phase of the module draft. The approach of Sidek Module Development Model can be seen in the following figure 1 :

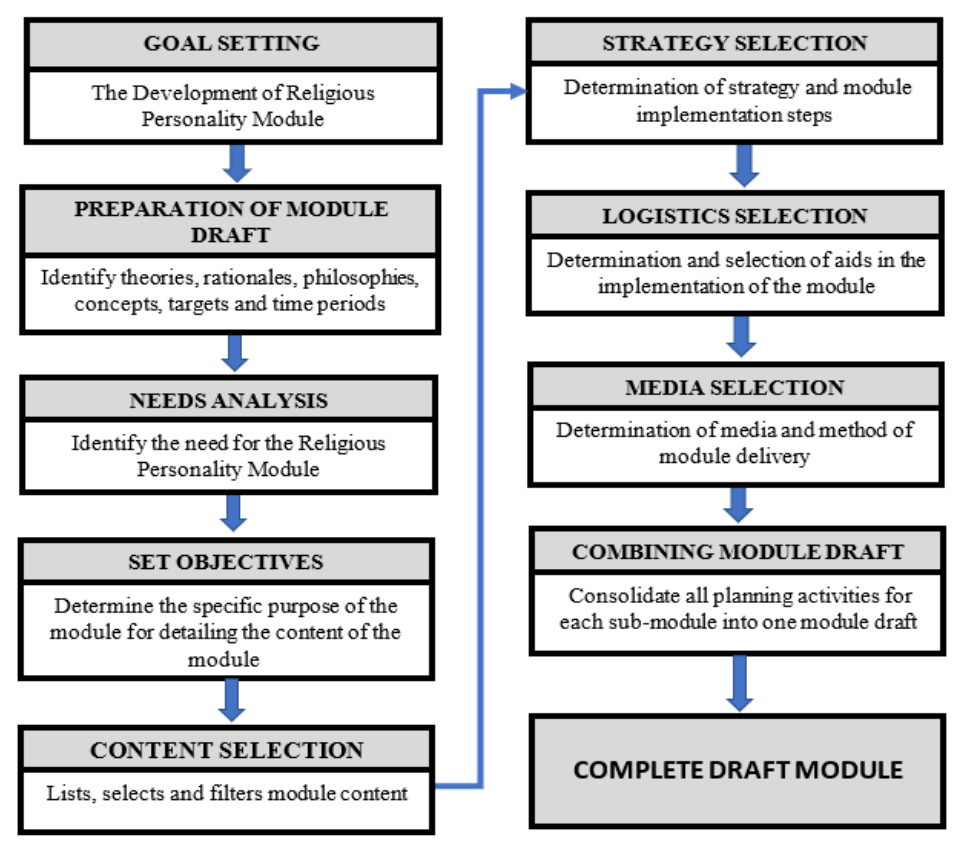

Figure 1. Preparation of Draft Module

Sidek Module Development Model (Sidek \& Jamaluddin, 2005).

MRPI Muslim Religiosity-Personality Inventory Model

The main construct of religious personality development in the draft of this module is based on the Model of Muslim Religiosity-Personality Inventory (MRPI) (Krauss et al., 2005). Based on this model, there are two main constructs in measuring the level of religiosity of a Muslim, namely Tasawwur Islam (Islamic Worldview) and Religious Personality (Religious Personality). The Islamic Tasawwur construct focuses on the paradigm of tawhid, namely belief and understanding of the six pillars of faith. While the construct of Religious Personality (Religious Personality) is a manifestation of tawhid in the form of pious deeds that include aspects of motivation, behavior, attitude and emotions (Adnan et al., 2017; Krauss et al., 2005). This study only used the Religious Personality construct in constructing the module draft. This is in line with the objective of the module which is to build the level of religious personality among students. There are three dimensions under the construct of Religious Personality, namely Own Self, Social Relationships and also Worship.

\section{i) Own Self}

This dimension is related to the religion-based aspect of the personal self from an Islamic perspective. This refers to the internal aspects of oneself as well as external or physical aspects which refer to the health and physical condition of an individual. The inner aspects of the self-include the good and bad values possessed such as humility, decency, courage, 
compassion, honesty, jealousy, envy, composure and so on. This can be detected through statements about attitudes, motivations, emotions and practices or behaviors. This dimension describes a person's relationship with Allah SWT based on self -condition, health and so on (Krauss et al., 2005).

ii) Social Relationships (Interpersonal)

This dimension refers to aspects of social and interpersonal relationships that are in line with Islamic teachings. This includes the ability to understand, work and relate to fellow human beings such as neighbors, family, friends and others. This dimension also looks at the extent to which a person responds to the motivations and feelings of others. This dimension describes a person's relationship with Allah SWT based on one's behavior towards others and also his relationship with other creations of Allah SWT (Krauss et al., 2005).

iii) Worship

This dimension looks at the practices and efforts of a person related to the worship of Allah SWT. Unlike the previous two dimensions, the dimension of worship reflects a person's direct relationship with Allah SWT through the practice of worship such as prayer, fasting, reading the Qur'an, giving alms and others. This dimension also includes compliance with Islamic laws and legislation, especially those that are external in nature such as the dress and appearance of a person. Therefore, this dimension can describe the level of commitment of a person (iltizam) to worship to Allah SWT. The MRPI Muslim Religiosity-Personality Inventory (MRPI) model can be seen in the following figure 2 :

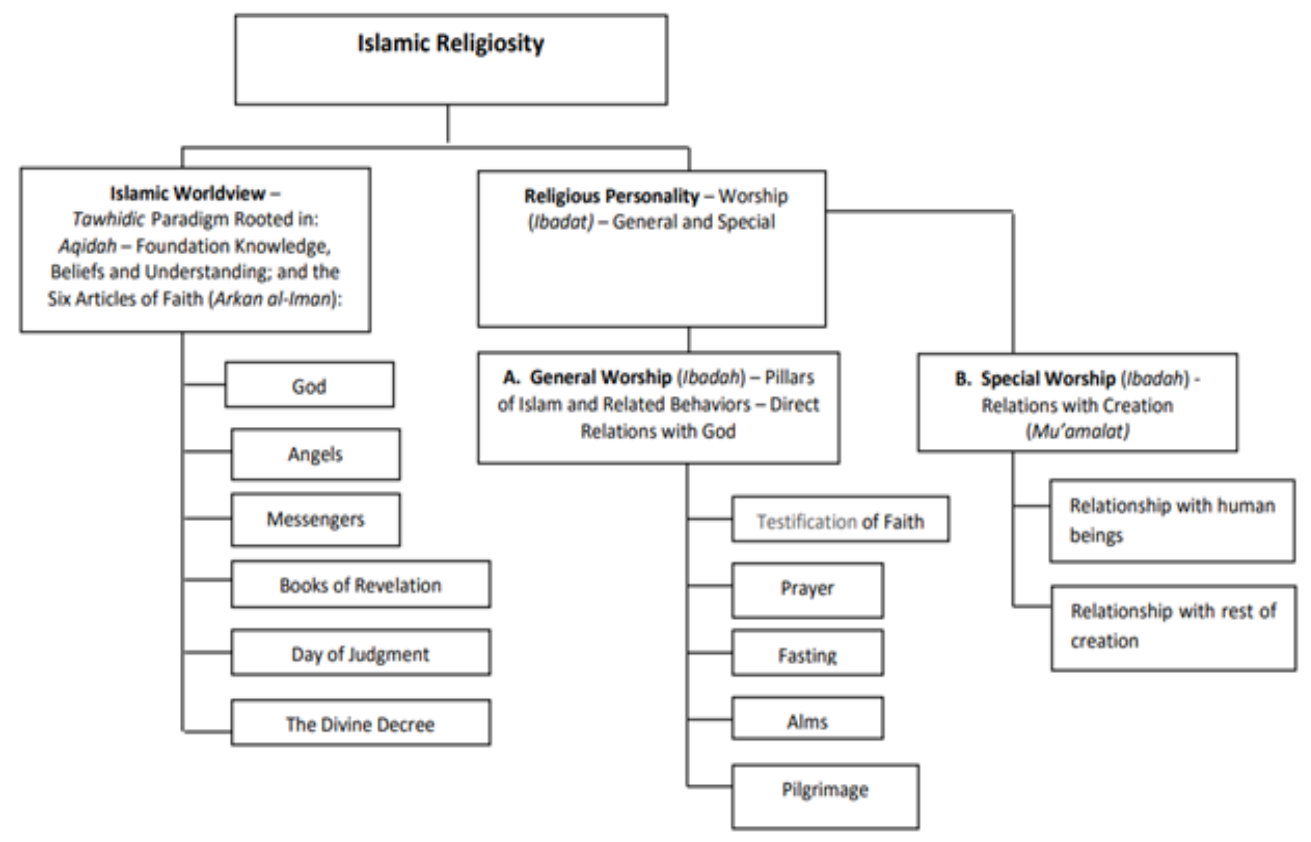

Figure 2. Model of Muslim Religiosity-Personality Inventory (MRPI)

(Krauss et al., 2005).

The dimensions of the Religious Personality construct are as in table 1 below: 
Table 1. Dimensions of Religious Personality Constructs Based on Islamic Beliefs

\begin{tabular}{|l|l|}
\hline MRPI Sub Dimension & The Concept of Islamic Beliefs \\
\hline Own Self & Relationship with oneself \\
\hline $\begin{array}{l}\text { Social } \\
\text { (Interpersonal) }\end{array}$ & $\begin{array}{l}\text { Relationship with human and } \\
\text { nature }\end{array}$ \\
\hline Worship & Relationship with Allah SWT \\
\hline
\end{tabular}

(Krauss et al., 2005).

Based on the dimensions of the religious personality construct in this MRPI model, the study has focused on the construction of four relationships namely relationship with Allah SWT, relationship with human, relationship with nature and relationship with oneself as the main constructs of the module draft. This coincides with the objective of the module which is to build and enhance religious personality among students.

\section{Al-Ghazali Religious Personality Model}

This study has made al-Ghazali Religious Personality Model a sub-construct in the construction of the module draft. This is because this model has been used by previous researchers in forming religious personalities and also in implementing modular spiritual guidance programs (Sa'ari \& Muhsin, 2012; Tahir et al., 2018; Jusoh. et al., 2018; Saper, 2012). Nevertheless, the integration between this model and the MRPI Model is a novelty and a new approach in the study.

According to al-Ghazali (1988), personality is encompassing the whole of the individual selfconsisting of physical (external) and spiritual (internal) aspects. These two aspects influence each other where the internal consisting of emotions, attitudes, motivations etc. can influence external behavior and external behavior can also affect the spiritual (Sham et al., 2013). Even so, according to al-Ghazali (1988) the spiritual aspect is seen to be more influential to the behavior and embodiment of a person's personality because it is related to the role of the heart. In addition to the heart referred to as qalbun, fuaadun and lubbun, alGhazali also discusses the role of nafs and intellect in the construction of Muslim personality.

Therefore, in ensuring that the Muslim personality is formed from the heart, nafs and intellect that are submissive and obedient to the commands of Allah SWT and Rasulullah SAW, then the process of purification of the soul (tazkiyyah al-nafs) must be done. According to alGhazali (1988), the process of tazkiyyah al-nafs needs to go through two more processes called mujahadah al-nafs (al-takhalli) and riyadhah al-nafs (al-tahalli). Mujahadah al-nafs means trying hard (mujahadah) against lust until the elimination of the attributes of mazmumah (abomination) such as jealousy, love of the world (hub al-dunya), riya', arrogance and so on. Riyadhah al-nafs is a training of the soul where the soul is trained with goodness gradually so that something that is considered difficult can finally be implemented easily and lightly (Sham et al., 2013, Ismail et.al, 2021).

These two processes complement each other in the construction of the Muslim personality where mujahadah al-nafs removes the attributes and practices of mazmumah (vile) and riyadhah al-nafs builds the attributes and practices of mahmudah (praiseworthy) in a person. The relationship of these processes can be seen in the following figure 3 : 


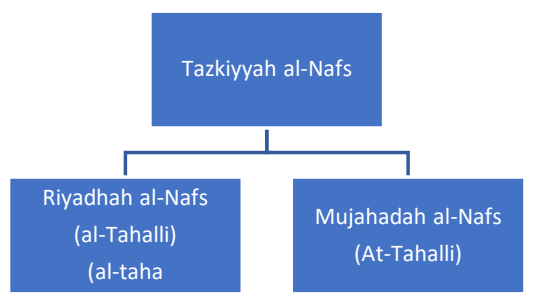

Figure 3. Al-Ghazali Religious Personality Model

(Al-Ghazali, 1988, Sham et.al, 2005)

In this study, the concepts of mujahadah al-nafs and riyadhah al-nafs are used as subconstructs in the module draft. This sub-construct is used as the basis in the construction of 12 module activities that focus on the development of religious personality.

Draft of Religious Personality Module

Based on al-Ghazali's Model of Religious Personality and the MRPI Model, as well as findings from a critical and extensive literature review, a draft module has been developed and produced as shown in Figure 4 below:

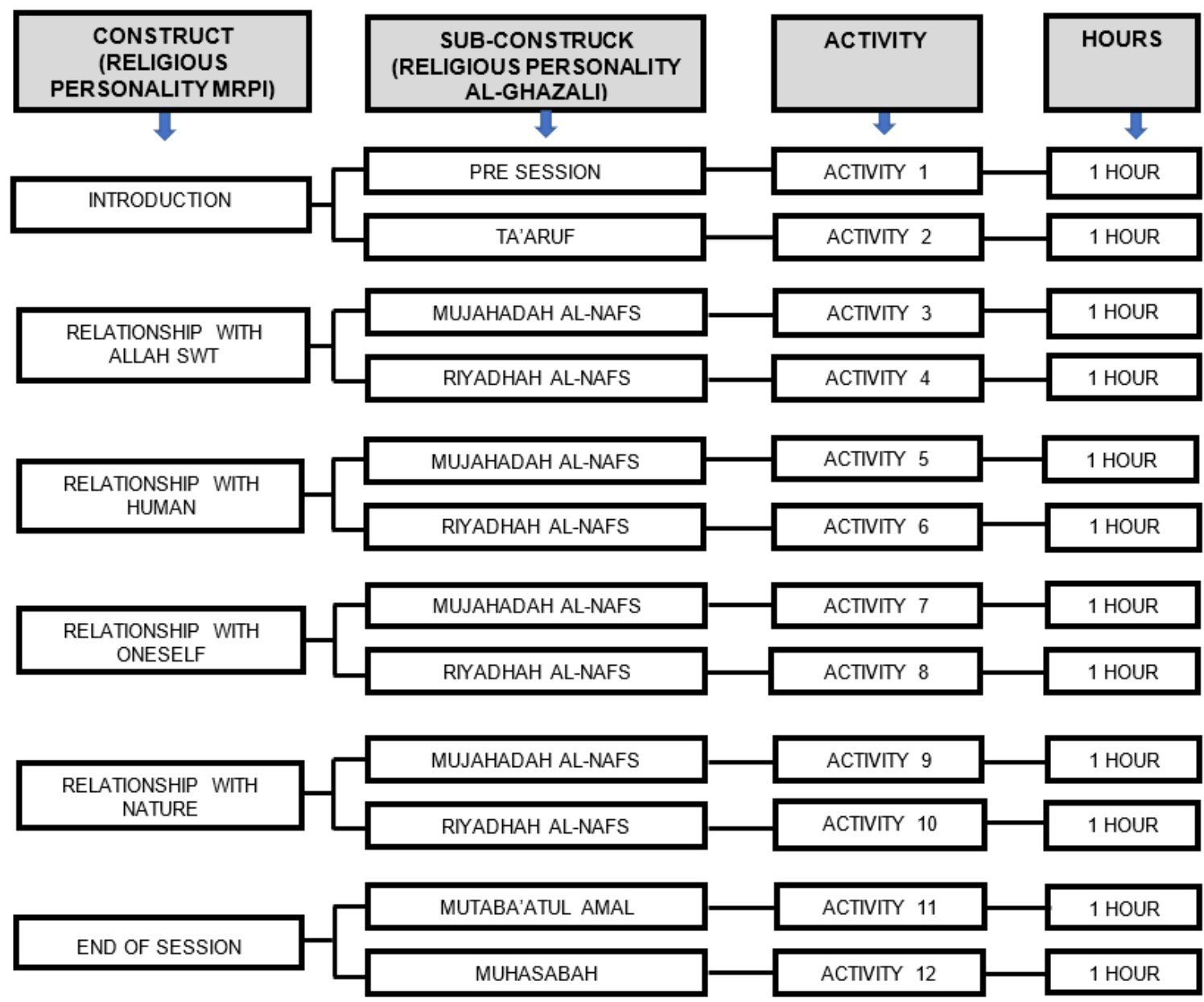

Figure 4. Draft of Religious Personality Module 


\section{Conclusion}

The study of module construction based on al-Ghazali Religious Personality Model and MRPI Model discussed in this article has produced a draft of Religious Personality Module with 12 activities in total. The Sidek Module Development Model was found to be suitable as a guide and basis in the module construction process because it has systematic and structured module construction stages. Findings in the construction of the draft of this module can contribute to the development and applicability of the module for peer spiritual guidance programs at the school level and institutions of higher learning, especially in the construction of religious personalities. Therefore, it is recommended that empirical studies be conducted to evaluate the validity, reliability and effectiveness of the module. The result is hoped to provide a new alternative to schools and institutions of higher learning in producing students as a holistic human capital of the country.

\section{Corresponding Author}

Noraini Ismail

Universiti Teknologi MARA Cawangan Perlis, Kampus Arau, 02600 Arau, Perlis, Malaysia

Email: noraini045@uitm.edu.my

\section{References}

Adnan, A. A. Z., Mastor, K. A., Kasan, H., \& Hamzah, F. M. (2017). Religiosity as a mediation factor of muslim work behavior. Jurnal Hadhari, 9(1), 141-156.

Al-Ghazali. (1988). Ihya' Ulum al-Din (Trans: Prof. TK. H. Ismail Yakub (ed.)). Singapore: Pustaka Nasional Pte. Ltd.

Ali, H. A. (2006). Salah Laku Remaja Masa Kini : Cabaran dan Penyelesaiannya. Shah Alam: Pusat Pemikiran Dan Kefahaman Islam.

Ghani, M. I. M., \& Musa, N.Y. (2018). Tahap personaliti beragama pengguna tandas masjid. INSANIAH: International Online Journal of Language, Communication, and Humanities, 1(1), 44-55.

Hamjah, S. H., Rozali, E. A., Rasit, R. M., \& Ismail, Z. (2012). Perkaitan amalan spiritual dengan pencapaian akademik pelajar. ASEAN Journal of Teaching \& Learning in Higher Education, 4(2), 51-60.

Ismail, N., Makhsin, M., Nasirun, N., Ismail, U. S., Abdul Pisal, N., Hashim, N., \& Noor, A. M. (2021). A Study of At-Takhalli and At-Tahalli Practices among University Students. International Journal of Academic Research in Business and Social Sciences, 11(7). https://doi.org/10.6007/ijarbss/v11-i7/10524

Muhammad, N. H. N., \& Omar, S. H. S. (2017). Peranan sahsiah dan kerohanian bagi mengatasi masalah penagihan dadah. In M. Z. M. @ M. Rahimah Embong (Ed.), Proceeding of International Conference of Empowering Islamic Civilisation (pp. 204-211). Research Institute For Islamic Product and Malay Civilisation (INSPIRE), UNISZA.

Sa'ari, C. Z., \& Muhsin, S. B. S. (2012). Cadangan model psikoterapi remaja Islam berasaskan konsep tazkiyah al-nafs. Jurnal Usuluddin, 36, 49-74.

Sham, F. M., Hamjah, S. H., \& Sharifudin, M. J. (2013). Personaliti Dari Perspektif al-Ghazali (Cetakan Ke2). Bangi: Penerbit Universiti Kebangsaan Malaysia.

Saper, M. N. (2012). Pembinaan Modul Bimbingan Tazkiyyah al-Nafs dan Kesannya Keatas Religiositi dan Resiliensi Remaja. Tesis Doktor Falsafah. Universiti Utara Malaysia. 
Shis, M. A. B. (2011). Kajian Gejala Sosial Dikalangan Pelajar Institusi Pengajian Tinggi Yang Menetap di Kolej Sembilan, Kolej Sepuluh dan Kolej Perdana Universiti Teknologi Malaysia. Tesis Sarjana, Universiti Teknologi Malaysia.

Tahir, A. F. M., Aini, Z., \& Rasit, R. M. (2018). Perubahan personaliti berdasarkan faktor agama menurut perspektif Islam. E-Journal of Islamic Thought and Understanding, 2(1), 60-79. https://doi.org/10.1017/CBO9781107415324.004

Sidek \& Jamaluddin. (2005). Pembinaan Modul: Bagaimana membina modul latihan dan modul akademik. Serdang: Penerbit Universiti Putra Malaysia.

Krauss, S. E., Hamzah, A., Suandi, T., Noah, S. M., Mastor, K. A., Juhari, R., Kassan, H., Mahmoud, A., \& Manap, J. (2005). The Muslim Religiosity-Personality Measurement Inventory (MRPI) Religiosity Measurement Model: Toward filling the gaps in religiosity research on Muslims. Pertanika Journal of Science and Technology, 13(2), 131-145. https://doi.org/10.1179/jfa.1974.1.1-2.3

Krauss, S. E., Hamzah, A., Juhari, R., \& Hamid, J. A. (2005). The Muslim Religiosity-Personality Inventory (MRPI): Towards understanding differences in the Islamic religiosity among the malaysian youth. Pertanika Journal Social Science \& Humanity, 13(2), 173-186.

Jusoh, S. M., Sharif, F., \& Sulong, J. (2018). Pembangunan kerohanian menurut model tazkiyah al-nafs al-ghazali: aplikasinya dalam pelaksanaan program tarbiah di asrama Sekolah Sekolah Menengah Kebangsaan Agama (SMKA), Pulau Pinang. 6th International Conference in Islamic Education: Rabbani Education 2018, 252-262.

Ghani, Z. A., \& Mansor, N. S. A. (2006). Penghayatan agama sebagai asas pembangunan pelajar: analisis terhadap beberapa pandangan Al-Imam Al-Ghazali. National Student Development Conference (NASDEC)., 1-19. 